\title{
The work and the health of elderly butchers: case reports from a municipal market
}

\section{Abstract}

The present study aimed to verify the health and work conditions of seven elderly workers carrying out informal labor activities in a municipal market and to describe the accidents they suffered at work. A qualitative case study was carried out with seven elderly butcher workers from a municipal market in Bahia, Brazil. The participants were men and women with limited schooling (up to high school level in one case), who lived with others at home and had worked for an average of 31 years in the butcher business. Despite the stress involved, such as uncomfortable physical positioning and few days off, all the participants said they were satisfied with their jobs. They were affected by chronic diseases, especially arterial hypertension, and said they were aware of the risks involved in their work. They had suffered accidents at work from finger cuts to amputation. Such workers require activities that promote health and protection from work-related accidents and injuries to avoid the problems that transform the process of senescence into senility.

Marcela Andrade Rios' Alba Benemérita Alves Vilela ${ }^{2}$ Adriana Alves Nery²

\section{Keyworks: Elderly.} Comorbidity. Chronic Disease. Health of the Elderly. Polypharmacy. SelfPerception of Health.

\footnotetext{
Universidade do Estado da Bahia, Departamento de Educação, Campus XII. Guanambi, BA, Brasil.

2 Universidade Estadual do Sudoeste da Bahia, Departamento de Saúde II, Programa de Pós graduação em Enfermagem e Saúde. Jequié, BA, Brasil.
} 


\section{INTRODUCTION}

Changes in demographic patterns in Brazil, including an increase in life expectancy, have influenced the labor market, with an increasing number of elderly people continuing to work.

Discussions about the relationship between work and aging are most often the result of a significant proportional increase of the elderly in the population, which has generated changes in ways of living and working.

Article 26 of the Statute of the Elderly deals with the right of the elderly person to perform professional activities, respecting their physical, intellectual and psychological conditions ${ }^{2}$. However, the realities in which these processes are constructed reveal that the minimum conditions of permanence are not always guaranteed for the elderly population, which often results in the insertion or continuation of these subjects in the informal market of the economy ${ }^{1}$.

Work plays an important role in people's lives, especially as a source of guaranteed social reproduction. The form of the organization and type of work are fundamental for evaluating the processes of damage and deterioration to the health of workers ${ }^{3}$.

The new socioeconomic model, which encompasses the informal sector, is due, among other reasons, to the influence of globalization, which has led to structural changes resulting from capitalist practices, resulting in a restructuring of the labor market, employment and the labor force to adapt to this new world ${ }^{4}$. In this context of changes, the availability of the workforce may encompass, in a broader sense, less permanence or reinsertion as employees, but more entry or permanence in both self-employment and as small business owners, in a world of heterogeneous work that houses a greater contingent of "old" workers ${ }^{5}$.

The informal sector encompasses a diversity of jobs, including retail. In this type of activity, the workplace is often the city streets or in specific buildings, such as supply centers or the municipal market. This scenario includes butchery workers.
According to a study carried out with informal butchery workers, such individuals have a risk of work accidents almost three times higher than market workers who sell ready-made foods and beverages ${ }^{6}$.

In this context, elderly butchers, in addition to the natural wear and tear of the body, may suffer from external factors arising from the labor process, especially when it is informal, leading to the occurrence of occupational accidents. It is therefore interesting to study elderly persons who continue to actively perform their work activities, especially in butcher shops and stalls, as they are exposed to a greater risk of suffering work accidents, in order to reveal the complexity of the health and labor conditions of these workers.

The aim of the present study was to verify the health and labor conditions of seven elderly workers performing informal activities in a municipal market in Bahia, Brazil, and to describe the work accidents they suffered.

\section{METHODS}

An exploratory, qualitative, field-based casestudy was carried out in which one or a number of individuals with the same disease or event are sought and, from the description of the respective cases, a profile of its main characteristics is drawn ${ }^{7}$, allowing the understanding of a set of phenomena that reveal a degree of comparability between one another and which relate in a given context ${ }^{8}$.

Seven workers aged 60 or older (considered an elderly person in Brazil $)^{2}$ working as informal butchers in a municipal market in the interior of Bahia, Brazil, participated in the study. These workers were included as they all reported having suffered at least one work related accident in the previous 12 months.

Work accidents were considered to be any reports of sudden events occurring in the exercise of work activities, which resulted in damage to health, potential or immediate, causing bodily injury or functional disturbance? 
Data were collected in the months of January and February 2015 through the application of a form with questions related to sociodemographic characteristics, work in the market, aspects of health and work accidents suffered. One of the evaluated aspects regarding work related to job satisfaction. This was investigated by means of a Likert-type scale ranging from not at all satisfied to very satisfied. Those who reported being satisfied or very satisfied with work were considered as labor satisfied. A field diary was also used to record the impressions of the researchers.

For the analysis of data, three categories were previously established to be presented and discussed, relating to sociodemographic aspects, work at the market and the health-illness-work process.

The present study is part of the umbrella research project entitled Labor Conditions and Health of Market Butchers in a Medium-Sized City in the State of Bahia, approved by the Ethics Research Committee of Universidade do Estado da Bahia (Bahia State University), under CAAE n. 44126515.5.0000.0057. All the workers interviewed agreed to participate in the study by signing a free and informed consent form.

\section{Case studies}

The Guanambi municipal market began in the $17^{\text {th }}$ century, due to the gathering of people and troops for the exchange of merchandise. The bruaqueiros or drovers, as the first users of the market were known, gathered around an umbuzeiro tree in the region where the square lies today to exchange goods. Years later, in 1951, a covered building was built for the municipal market. In 1988 the facilities were renovated and the market was expanded, and some of the pavilions where goods are still sold today were built. The Guanambi market is considered one of the most important of the Bahian sertão (drylands region) ${ }^{10}$.

The butchery area occupies two pavilions of the Municipal Market, and comprises approximately 97 workers, according to the accounting taken by researchers in 2015, of whom 12 are elderly. Elderly persons who described having suffered a work accident in the last 12 months, were studied, which included seven cases (five men and two women).
Ages ranged from 62 to 78 years. The women were aged 62 and 69 years and of the men two were 69 and the others were 75 and 78 . Five of the workers interviewed lived with a partner; two were divorced/separated; all were fathers or mothers, with an average of five children each, varying between two and 11. None lived alone at home, but resided with between two and six persons in the same house.

They had little or no schooling (one never attended school, four described up to six years of study, one had completed elementary school, or in other words had nine years of schooling, and another had completed high school, or had 12 years of schooling).

Describing the characteristics of the work performed by elderly butchers is important for understanding the life and work trajectory of these individuals and its interconnection with the healthdisease-work process.

The interviewees had worked for on average 31 years at the market, ranging from 13 to 50 years. All were owners of the butcher shops/ stands. Four (three men and one woman) had previously worked as farmers, one had been a teacher, one had always worked as a butcher and the other had been a military police officer. Everyone started working between the ages of five and 15. They wake up between 2:00 a.m. and 6:00 a.m. to get to the market, thus beginning their day's work. One man and one woman worked every day of the week, with no breaks or days off.

They performed a variety of activities in the butcher shop: cutting, deboning or serving customers at the counter. Four women also described slaughtering animals. One man and one woman, in addition to these functions, also cleaned the work area and described using chemical products, such as chlorine, but did not use protective equipment. In non-participant observation it was noticed how the work of cutting, weighing and pack the product is done quickly, attending to the customers' needs.

Both data collection and observation showed how exhausting work at the market can be. Three workers described carrying heavy weights all the time; five performed a lot of repetitive movement; the butchers worked on foot almost all the time; and four said 
that work is very stressful. Only two (both men) reported using personal protective equipment. The non-use of PPE, especially gloves suitable for cutting and deboning and goggles, was also noted during observation and later recorded in the field diary.

Despite the stress described, caused by uncomfortable positions and a lack of days off, everyone agreed that they are satisfied with the work.

In order to better understand the health-diseasework process, it is necessary to analyze general and specific information about illness and accidents at work, whether the same are related to work or not, since the existence of pathologies or pathological processes can influence labor activities, as well as leading to the development of diseases and occurrence of accidents.

In terms of the health characteristics of the studied workers, two reported feeling constant pain in their backs and having a medical diagnosis of arthrosis. Five had a medical diagnosis of arterial hypertension (two women and three men), one had hearing problems and used an appliance, and another had diabetes mellitus. Some also reported respiratory problems such as rhinitis, asthma and chronic bronchitis.

When questioned about the health problems that affect her and how these can impede the correct performance of her work, one butcher believed that she was unable to work but needed the income to survive and support her family. This same worker said that she does not believe, from a health perspective, that she will be able to perform her labor activities at the market in two years' time. Two workers said they had suffered no impairment of their duties. The others said that they sometimes needed to slow their work down, that is, their health affected the work process and vice versa. Four workers, all men, had not visited any health services in the last year.

One notable factor that was described in the field diary was the difficulty the workers had leaving the butcher shop, especially in those establishments where only the owner was present and which did not have employees. They stated that when leaving or closing the establishment they stop selling and are therefore denied income.
All interviewees reported perceiving health risk factors in the performance of their work: electric shocks, finger and hand cuts when handling knives, chainsaws and meat mincers/grinders, temperature changes, stress at work, traffic accidents on their way to or from the market and robberies.

As for work-related accidents, one of the workers reported an average of 50 physical injuries in the last 12 months. Two others reported one accident, while the others reported two, three, four and five, respectively. One accident did not cause evident physical injury as it was an electric shock from using butchery machinery.

In order to obtain information about such accidents, the individuals were questioned about the characteristics of the last event suffered. These were: upper limb fracture, an accident that caused loss of mobility as it affected the nerve endings and required hospitalization; a cut with finger amputation; leg fracture and cuts on hands/fingers.

The workers descriptions of the accidents were worthy of note, as all considered themselves to blame and described a lack of care and/or haste to perform the job as the reasons for the event.

\section{DISCUSSION}

Throughout his existence man has been driven to work continuously in order to guarantee his and his family's subsistence. It is through work that man, as an effective social being, performs the act of producing and reproducing. In this context, to be outside the labor market is to be outside of life, excluded from the conditions of social reproduction ${ }^{11}$. The elderly therefore remain in the labor market, even in the informal capacity in which they have always performed due to a lack of opportunity in the formal market, most likely due to their low levels of schooling.

The aging process must not only be associated with loss, since elderly persons can experience an active aging ${ }^{12}$, a process which includes continuing in the labor market.

Individuals aged 60 years and over are often able to continue to exercise their professional activities as 
they have the physical and intellectual capacity for new ventures and possess accumulated knowledge and experience that cannot be overlooked ${ }^{13}$.

This reinsertion or continuation in the market may also occur because in many cases the elderly worker is still considered the support for his or her family. In most cases, the low value of pensions does not meet the basic needs of the retired worker, such as health, food, medicines, housing and leisure. Based on this assumption, elderly persons seek to return or remain in the informal labor market to increase family income ${ }^{14}$. In this context, from the reports of the cases, two reasons were verified as to why elderly person still work: the need for income and the need for personal satisfaction.

In a study carried out with elderly informal street workers ${ }^{14}$, it was found that such individuals considered themselves to be doubly excluded from the formal labor market, due to age, as they are already retired in many cases (therefore, retirement also functions as an element of exclusion) and not being qualified for the current job market. The study also showed that work represents a source of income, distraction and domestic power for the elderly. Work was also considered a source of pride ${ }^{14}$.

However, labor activities directly affect the health of elderly butchery workers. The individuals do the work; it is from them that the commitment is demanded; it is they who analyze the conditions they possess to carry it out; it is they who suffer physical, mental and emotional exhaustion; it is they who, in the end, fall ill, suffer accidents and die ${ }^{15}$.

The above quote sums up the experiences revealed from studying the seven cases of elderly butchery workers. They have dedicated themselves to many years of work at the market, they have little or no schooling, they often still need to work to supplement the income of their family or to assert themselves as social beings. However, they have chronic noncommunicable diseases or painful spinal injuries and their health is even more affected when they suffer accidents when carrying out their work.

Among the occupational groups vulnerable to chronic diseases such as arterial hypertension, market workers are at particular risk because they perform their work in direct contact with different people and products, during a work day of ten hours a day or more, often without holidays or weekly days off, while undergoing financial instability due to a variable monthly income, the exposure to physical risks, and limited time available for health care. Such living and working conditions may increase the likelihood of harm to human health ${ }^{16}$.

In this sense, the work process is directly related to the health-disease process, as adverse working conditions can lead to diseases and injuries. The daily life of the market is permeated by difficulties and challenges, which require changes in life habits ${ }^{17}$. According to researchers ${ }^{18}$, health problems reduce productivity and work performance and increase the occurrence of accidents and injuries.

One of the tasks performed by workers who sell meat and poultry involves the carving and cutting of goods with the use of both motorized and manual tools, which can lead to the risk of injuries to the hands and fingers. Another factor that must be addressed is the pressure of productivity, as most commercial sellers are the owners of the commercial unit where they work and their monthly income is based on the quantity of merchandise sold, that is, it depends on the value of sales/revenues. This variation in income based on productivity can lead to physical and psychological exhaustion, increasing the chances of accidents and the development of work-related diseases ${ }^{19}$.

Despite suffering from chronic noncommunicable diseases and reporting the occurrence of work accidents, including an amputation, all the workers reported satisfaction with work.

Job satisfaction is a difficult term to conceptualize as it is a subjective state and so varies from individual to individual. The most commonly used concept concerns emotion, that is, satisfaction at work is a pleasant feeling that results from the perception that work achieves or allows the realization of important values relative to the work itself ${ }^{20}$.

Satisfaction is based on perception of the current situation in relation to values. Perceptions may not reflect objective reality with complete precision, and when they do not, one must value the individual's perception of the situation and not the situation itself ${ }^{20}$. In this sense it is inferred that workers may 
expect no more from their work than what it is, so that the results are expected, which in turn leads to satisfaction with work.

It is important to note the attribution of the responsibility for accidents at work to the victims themselves, since all the interviewees pointed out haste and lack of care as possible causes for these events, which leads us to consider social acceptability and the workers' own "unsafe acts". However, from a scientific point of view, and in particular from the state of the art of research in the field of the analysis of disasters and accidents at work, the persistence of the use of the notion of unsafe acts is unacceptable $e^{21,22}$. A visualization of the whole work process is necessary so that the causes are more evident.

\section{CONCLUSION}

Elderly persons often remain in the labor market, albeit informally, for reasons of personal satisfaction or to supplement family income. The butchers in the present study had worked for a time at another job or had a family tradition of working in the trade. However, they are exposed to risks present in the labor process which can lead to the occurrence of accidents at work and/or the development and aggravation of pathological processes. Many already suffer from illnesses such as chronic nontransmissible diseases.

Even with the occurrence of accidents, the interviewees studied continue to be satisfied with their work and propagate the idea of the unsafe act as the cause of the accidents.

In view of the process of population aging and the consequent increase of the elderly workforce in Brazil, there is a clear need to strengthen policies for active and healthy aging that encompass the work process with regard to the promotion of health and the prevention of diseases and injuries arising from or aggravated by work.

\section{REFERENCES}

1. Melo SP. Trajetórias de feirantes idosos: relações de proximidade, corpo e trabalho. Estud Iinterdiscipl Envelhec. 2014;19(1):265-85.

2. Brasil. Legislação sobre o idoso: Lei $n^{\circ} 10.741$, de $1^{\circ}$ de outubro de 2003 (Estatuto do idoso) e legislação correlata [Internet]. $3^{a}$ ed. Brasília, DF: Edições Câmara; 2013 [acesso em 15 jul. 2017]. Disponível em: http://www.planalto.gov.br/ccivil_03/leis/2003/ L10.741.htm.

3. Ferreira DK, Bonfim C, Augusto LGS. Condições de trabalho e morbidade referida de policiais militares, Recife-PE, Brasil. Saúde Soc. 2012;21(4):989-1000.

4. Marques APP. Reestruturação produtiva e recomposições do trabalho e emprego: um périplo pelas "novas" formas de desigualdade social. Ciênc Saúde Coletiva. 2013;18:1545-54.

5. Guimarães IR. Os idosos em um contexto de trabalho e de disposições renovadas. Mediações. 2012;17(2):108-25.

6. Rios MA, Nery AA, Rios PAA, Casotti CA, Cardoso JP. Fatores associados a acidentes de trabalho envolvendo trabalhadores informais do comércio. Cad Saúde Pública. 2015;31(6):1199-212.
7. Pereira MG. Epidemiologia: teoria e prática. Rio de Janeiro: Guanabara Koogan; 2008.

8. Yin RK. Estudo de Caso: Planejamento e Métodos. $5^{\text {a }}$ ed. Porto Alegre:Bookman; 2015.

9. Brasil. Ministério da Saúde. Secretaria de Atenção à Saúde. Departamento de Ações Programáticas Estratégicas. Notificação de acidentes do trabalho fatais, graves e com crianças e adolescentes. Brasília, DF: MS; 2006.

10. Cotrim DT. Guanambi: aspectos históricos e genealógicos. Belo Horizonte: Cuatiara; 1994.

11. Teixeira SM. Envelhecimento e trabalho no tempo de capital: implicações para a proteção social no Brasil. São Paulo: Cortez; 2008.

12. Freitas EV. Demografia e epidemiologia do envelhecimento. In: Py L, Pacheco JL, Sá JLM, Goldman SN. Tempo de envelhecer: percursos e dimensões psicossociais. $2^{a}$ ed. Holambra: Setembro; 2008.

13. Muniz TS, Barros A. O trabalhador idoso no mercado de trabalho do capitalismo contemporâneo. Ciênc Hum Soc. 2014;2(1):103-16. 
14. Coutrim RME. Idosos trabalhadores: perdas e ganhos nas relações intergeracionais. Socie Est. 2006;21(2):367-90.

15. Cardoso ACM. O trabalho como determinante do processo saúde-doença. Tempo Soc Rev Sociol USP. 2014;27(1):73-93.

16. Vale PRLF, Santos TP, Saturnino MN, Aguiar MGG, Carvalho ESS. Itinerarios terapeuticos de feirantes diante das necessidades de saude dos familiares. Rev Baiana Enferm. 2015;29(4):372-81.

17. Silva SRA, Amorim RC, Almeida AM. Percepção de feirantes hipertensos sobre o adoecer crônico. Rev Enferm UERJ. 2015;23(6):761-6.
18. Mäkinen TM, Hassi J. Health problems in cold work. Ind Health. 2009;47:207-20.

19. Rios MA, Nery AA. Condições laborais e de saúde referidas por trabalhadores informais do comércio. Texto \& Contexto Enferm. 2015;24(2):390-98.

20. Locke EA. What's job satisfaction? Org Beh Hum Perform. 1969;4(4):309-36.

21. Llory M, Montmayer R. L'accident et l'organisation. Bordeaux: Preventique; 2010.

22. Jackson Filho JM, Vilela RAG, Garcia EG, Almeida IM. Sobre a "aceitabilidade social" dos acidentes do trabalho e o inaceitável conceito de ato inseguro. Rev Bras Saúde Ocup. 2013;38(127):6-8. 